\title{
LEGAL ASPECTS OF CORPORATE SOCIAL RESPONSIBILITY IN UKRAINE ON THE WAY TO EUROPEAN INTEGRATION
}

\author{
Oleksandra Kolohoida, Iryna Lukach, Valeriia Poiedynok*
}

\begin{abstract}
Summary: Corporate social responsibility is a new form of dialogue between business, society and the state. This article explores the possibilities of legislating for corporate social responsibility in Ukraine in respect of implementing the Association Agreement of 2014 between the European Union and its Member States, of the one part, and Ukraine, of the other part. Different approaches to introducing corporate social responsibility standards are examined. The paper considers not only international literature regarding the subject, but also Ukrainian sources which are methodologically important concerning the economic and legal implementation of Directive 2014/95/EU. In conclusion, the legal ways of legislating for CSR are considered.
\end{abstract}

\section{Introduction}

In the present context, every modern state is facing important strategic social tasks: to build a civic society and improve its citizens' welfare. It is impossible to resolve these tasks without regulating the power of the state. In the modern world, cooperation between the state and corporations should not concern just taxation and opening new jobs. Nevertheless, the trends in the economic and legal corporate doctrine of the $20^{\text {th }}$ century prove that the social component of corporate activity is a supplement to its main function, ie profit-making. This is not possible without a certain amount of corporate involvement providing for the labour market and contributing to the state budget Given this, corporations are a strategic internal partner of the state in the sphere of stable economic development, and they form the basis of building European Union (EU) policies, as the EU countries have approached the process of regulation of the social role corporations play from a different perspective than that of the USA. Based on global experience, the concept of corporate social responsibility (hereinafter: CSR) may become a platform for interaction between the state, society and global corporations. However, the initia-

\footnotetext{
*Oleksandra Kolohoida, Iryna Lukach and Valeriia Poiedynok are professors in the Department of Economic Law of the Faculty of Law of Taras Shevchenko National University of Kyiv, Ukraine.
} 
tive regarding its introduction and implementation should be taken by the state, as has already happened in many Western European countries.

The Association Agreement between the European Union and its Member States, on the one hand, and Ukraine, on the other hand (hereinafter: Association Agreement) ${ }^{1}$ has established numerous tasks for Ukrainian legislation. One of them is to create conditions for enhanced economic and trade relations leading towards Ukraine's gradual integration in the EU internal market, including by setting up the Deep and Comprehensive Free Trade Area as stipulated in Title IV (Trade and Trade-related Matters) of the Agreement, and to support Ukrainian efforts to complete its transition into a functioning market economy by means of, inter alia, progressive approximation of its legislation to that of the Union. ${ }^{2}$ In this connection, a new approach to understanding corporate behaviour is required.

This article faces particular issues. First, CSR is a new approach in the research of Ukrainian corporate law. There are very few articles exploring CSR legal regulation, while the current economic CSR implementation has been examined in scientific literature only briefly. Second, general Ukrainian economic literature deals with studies of the history of CSR only, while the impact of implementing CSR in Ukrainian companies, or even deeper considerations - its impact upon legislation - is seldom under discussion. Third, some practical CSR implementation has already been attempted in other former Soviet countries. In many ways, Ukraine has similar problems in the context of economic and legislative history. On the other hand, Ukraine has its own unique approach to CSR in the Association Agreement context, as well as in the context of clearly preferred European perspectives. For this reason, the implementation of CSR by other former Soviet countries should be viewed in regard to the implementation of EU legislation.

\section{CSR research development}

At the beginning of this study, it should be noted that society's obligations are placed not only on its members but also on creditors and corporate management authorities. This idea was described in the stakeholder theory suggested by the economist M Freeman who stated that stakeholders were those who affected the achievement of corporate goals, while the corporation affected its stakeholders in the process of achieving its goals. ${ }^{3}$ Stakeholders are considered a part of the company - including

\footnotetext{
1 Association Agreement between the European Union and its Member States, on the one hand, and Ukraine, on the other hand [2014] OJ 161/3.

2 Association Agreement (n 1) art 1(2)(c).

3 M Friedman, 'The Social Responsibility of Business Is to Increase its Profits' The New York Times Magazine (New York, 13 September 1970) 31.
} 
customers, suppliers, financiers, creditors, shareholders, employees, local and national governments, tax authorities and local communities. ${ }^{4}$ The stakeholder theory allowed for an innovative assessment of the subjective structure of corporate relations and became the basis for the elaboration of many contemporary corporation theories, the CSR theory in particular.

In this context, it should be noted that CSR is not aimed at establishing balance between the interests of corporations, the state and society as the optimal model available. The first scientific research to understand the essence of CSR, its principles and methods was launched in the 1950s. The main role in elaborating this theory was played by American academics, while in Europe the CSR concept was officially formed only in the late $20^{\text {th }}$ century.

At the current stage of society's economic development, there has been a search for the ethical legitimisation of late capitalism through the prism of establishing a 'moral capitalism' principle. Therefore, as G Elkington states, 'businessmen all over the world acknowledge the fact that the key markets are on the verge of rapid changes conditioned by new environmental standards and connected to consumer demands. This results in the new bottom lines being deployed along the old "profit-loss" constants'. The trends mentioned by the researcher are the environmental, economic and social responsibility of any business, ie the formation of such economic thinking where business becomes a social factor, and its responsibility is understood not only as responsibility for its activity but also as responsibility before local communities adjoining such business activity area. ${ }^{5}$

Based on G Elkington's concept, managers have to make administrative decisions by relying not only on anticipated financial indices but also on the indices reflecting the social environmental purposes of corporate activities. The central thesis of the triple criterion concept is the preservation of the three types of capital - economic, environmental and social, for the purposes of providing for the long-term economic development of society. ${ }^{6}$

To unite the efforts of businessmen and trade unions, nongovernmental organisations and governmental agencies, and to direct such efforts to support and apply the ten universal principles related to human rights protection, labour standards and environmental protection, as well as to fight corruption, the United Nations Global Compact was signed in

$4 \quad$ F Easterbrook and DR Fischel, The Economic Structure of Corporate Law (Harvard University Press 1996) 2 .

5 J Elkington, The Zeronauts: Breaking the Sustainability Barrier (Routledge 2012) 50.

6 Elkington (n 5) 250. 
2000. This document is a voluntary initiative aimed at uniting socially responsible companies to exchange their experience in implementing respective programmes and projects. Currently, this treaty unites several thousands of companies from over 100 countries which form one of the largest voluntary initiatives in the world.

The most interesting thing is to assess the effect of corporate social activity on the reputation and indices of the main corporate activity. First, the assessment results confirm the hypothesis that social factors, along with economic ones, do affect the main activity indices of the company. Second, the research establishes the interdependence of social responsibility, reputation and trademark loyalty. ${ }^{7}$

In Article 3.1 of the Renewed EU Strategy for Corporate Social Responsibility 2011-20148 (hereinafter: Communication), the European Commission provides a new definition of CSR: the 'responsibility of companies for their effect upon society'. The precondition to achieve such responsibility is compliance with the effective legislation and collective agreements between social partners. To comply with the CSR requirements in full, companies need to have the ability to integrate social, environmental and ethical human rights and consumer aspects into their economic activity, as well as to introduce strategies by directly cooperating with the parties concerned, in order to maximise the share price for members/shareholders, stakeholders and society in general and to forecast, prevent and neutralise possible negative consequences.

\section{Current Ukrainian economic CSR issues}

Meanwhile, based on the UN research of Ukrainian business, 49.1\% of companies on average perform no monitoring of the social consequences of innovative development; $29.4 \%$ of companies do this from time to time, and only $5.3 \%$ of them use accurate indices. Judging by foreign experience, France pays much more attention to CSR matters as it has an effective law obliging every public company with business activity to report annually on the introduction of social programmes and on the prospects of innovative activity. ${ }^{9}$

SB Kim and DY Kim, 'The Impacts of Corporate Social Responsibility, Service Quality and Transparency on Relationship Quality and Customer Loyalty in the Hotel Industry' (2016) Asian Journal of Sustainability and Social Responsibility 12.

8 Commission, 'Communication to the European Parliament, the Council, the European Economic and Social Committee and the Committee of the Regions: A renewed EU strategy 2011-2014 for Corporate Social Responsibility’ COM (2011) 681 final.

9 N Voloskovets 'Corporate Social Responsibility as the Basis of Innovative Development of Modern Economy' (2010) 7 Scientific Works of Kirovohrad National Technical University: Economic Sciences 127. 
Ukrainian economists believe that the key problem in CSR regulation is the introduction of, and compliance with, the requirements of effective legislation in the sphere of socially responsible business behaviour for the formation and development of the domestic CSR model based on strategic partnership between the government and business. The need for social responsibility of business in Ukraine is conditioned by the following factors:

- the low level of corporate culture and the resulting financial and economic weakness of a large number of companies in Ukraine;

- legal nihilism and the deformation of legal awareness - the culture of respecting legal standards and law in general is at an early stage of development in Ukraine;

- the low level of appreciation by society of the role of business;

- the closed nature of Ukrainian companies;

- the uneven consideration of the interests of stakeholders: companies take more account of the interests of consumers and government authorities, and they are less concerned with nongovernmental and research organisations and education institutions with which there is hardly any cooperation. ${ }^{10}$

Other aspects of implementing SCR standards are state-owned corporations (SOCs). They amount to a considerable 16.3\% of the Ukrainian economy but in some specific areas this number is even higher. It should be noted that this sphere relates to strategic areas, along with agriculture (53.3\%), electricity transmission (49.6\%), scientific research (66\%), and transport (27.6). ${ }^{11}$ Unfortunately, the level of disclosure of Ukrainian SOCs is insignificant. Analysis of the SOCs' openness has shown that their average disclosure level is $10 \%$ (while for private companies this is $19 \%$ ). Most often, SOCs do not publish financial reports on websites; it is difficult to find policies and reports regarding social or environmental protection. ${ }^{12}$ In this regard, the introduction of CSR into SOCs without any exceptions is highly important; the paper will consider this subject further.

Thus, there is another problem: the information provided by SOCs is far from complete and lacks compliance with standards such as those

\footnotetext{
10 NO Shira and AI Ivashchenko, 'Directions of Implementation of the System of Corporate Social Responsibility in the Practice of Ukrainian Enterprises' (2013) 11 Efektyvna ekonomika.

11 Ministry of Economic Development and Trade of Ukraine, Specific Gravity of the Governmental Sector in the Economy <www.me.gov.ua/Documents / Download?id=19dffa6e-66b2449b-8df3-54b2e0a181e0> accessed 10 October 2017.

12 I Kurinna and others, Transparency and Corporate Social Responsibility (Poligrafia Yuston 2014) 5 .
} 
of the OECD. European economists insist that the information offered by SOCs and governmental authorities should comply with the OECD (2015) recommendations: ie, it has to be relevant, sufficient and reliable, and provided on a timely and regular basis in order to improve credibility. ${ }^{13}$

For the purposes of introducing innovations and developing an approach to CSR, flexible terms and conditions have to be stipulated for corporations. In this, the availability of principles and guidance issued by the governmental authorities are a reference point for many companies concerning their own policies and productivity.

It should be noted that the Communication also calls on nongovernmental organisations to participate in CSR. In particular, as specified in article 3.4 of part 3 of the Communication, trade unions and nongovernmental civil organisations are called on to identify problems and participate in setting up constructive cooperation with companies to find a joint solution. Consumers and investors may increase market remuneration for socially responsible companies through consumption and through the investment decisions they make. The mass media are able to raise awareness regarding the positive and negative effect of companies. Governmental authorities and other stakeholders have to demonstrate social responsibility, including responsibility in their relations with companies.

To sum up the importance of CSR, we should note that such a format allows not only present conflicts and contradictions to be ascertained but also for large businesses and governmental authorities to be connected, on the one hand, and the public represented by trade unions, associations and the mass media, on the other hand, within the frameworks of a single programme. This programme has the purpose of instilling a responsible attitude in corporations towards their social duties with the simultaneous maximisation of corporate profit, including that for the purpose of achieving an important social effect.

However, the modern Ukrainian legislation contains no general CSR principles. Individual aspects of respective government policy are mentioned in various government programmes, but Ukraine is not engaged in any complex activities regarding the introduction of CSR. Nevertheless, even with the lack of any support from the government, there is major public work - the book Best CSR Practices in Ukraine was published five years ago and has been regularly updated since then. ${ }^{14}$ The seventh edition includes 35 CSR practices from various companies in Ukraine. Quite

\footnotetext{
13 J-R Córdoba-Pachón, R Garde-Sánchez and M-P Rodríguez-Bolivar. 'A Systemic View of Corporate Social Responsibility (CSR) in State-Owned Enterprises (SOEs)' (2014) 21 Knowledge and Process Management 216.

14 CSR Practices in Ukraine <http://csr-ukraine.org/wp-content/uploads/2017/01/CSRcases-in-Ukraine-2016.pdf> accessed 9 May 2017.
} 
a number of the major Ukrainian corporations provide reports of their CSR-related activities on their websites, and this has a significant practical meaning at the international level as CSR is included in the system of many standards which we shall discuss below.

The assessment of the level of corporate social responsibility in Ukraine is complicated by the fact that the CSR reports are optional, and there is no single standard that might work; accordingly, such reports are provided by only a small number of enterprises, and the information contained therein often prevents comparative analysis of the level and range of social response of different enterprises. ${ }^{15}$ Such purposes must be clarified for the Ukrainian market players who sometimes lack information regarding CSR. In this aspect, it should be stressed that CSR in Ukraine is mostly viewed as charity work. Even the Best CSR Practices in Ukraine guide has no structured strategy and is more opinion-based journalism than a report with specific figures. It mostly focuses on charity work or help in building such things as football pitches. As will be shown later in the paper, modern understanding of CSR is that it is not only charity. Another complex issue that Ukrainian businesses mainly focus on regarding CSR is personal development. These issues are a top priority in Ukraine, where the levels of labour protection and salaries are still very low compared to Europe. But once again, as a rule, CSR reports are not structured. ${ }^{16}$

Some Ukrainian state companies do have structured social reporting. ${ }^{17}$ In Ukraine, the first CSR reports emerged in 2005. Since then and until 2016, 28 companies published 47 reports, with most reports filed in the period 2010-2013. Judging by CSR publications made by Ukrainian economists, there was a dramatic decline in CSR reports in 2014. This was mainly the result of the Donetsk Region situation which is currently beyond Ukraine's control and was annexed by a pro-Russian selfproclaimed formation. This situation has led to a massive anti-terrorism operation without a state of war actually being declared.

This tragic stage of Ukrainian history was the main reason for the rapid drop in CSR reports. Gross domestic product fell by $17.6 \%$ in 2015 (compared to 2013). ${ }^{18}$ Donetsk and Luhansk, being the epicentre of the conflict zone, saw industrial production decline by $32 \%$ and $42 \%$

15 E Kovalenko, 'Issues of Corporate Social Responsibility Development in Ukraine' (2015) Global and National Issues of Economic 153.

16 Kyivstar CSR Report <http://report.obolon.ua/ru/society/development_regions> accessed 18 June 2017.

17 Lifecell Social Reports <www.lifecell.ua/en/about_lifecell/social-responsibility/socialreports/ $\geq$ accessed 17 June 2017 .

18 Main Indices of Social and Economic Development of Ukraine <www.ukrstat.gov.ua/ operativ/operativ2015/mp/op_u/op0415_u.htm> accessed 18 June 2017. 
respectively. ${ }^{19}$ Economic losses were also very high on the corporate market. Market capitalisation of Ukrainian public companies dropped from UAH 542 billion (5 May 2015) to UAH 22 billion (5 May 2016). ${ }^{20}$ As of the end of 2014, out of 22,852 registered companies limited by shares, 2,081 were from the Donetsk or Lugansk regions. ${ }^{21}$ By the end of 2015, the number of companies limited by shares and registered in the Donetsk or Luhansk regions dropped to 1,142 . As many as $66.15 \%$ of these were located in the Donetsk Region where the Ukrainian government temporarily has no power, and $73.91 \%$ were in the same uncontrolled territory of the Lugansk Region. ${ }^{22}$

All these economic and social cataclysms have led to a general reduction of companies filing their CSR report; again, one has to remember that the reports in Ukraine have been made and filed on a voluntary basis since so far neither Ukrainian legislation nor stock market regulations have contained any CSR report requirements.

There are legal works regarding the social orientation of the economy in the sphere of economic law to introduce CSR in Ukraine which are cited in this paper to show that Ukrainian economists have conducted some research in this field. Special attention should be paid to the CSR of major corporations and the prospects for their enhancement as well as for a change of their identity as a result of consideration given to their important social contribution. Besides, it would be expedient to introduce voluntary CSR reporting by public companies limited by shares, but still to provide for its definition on a legislative level.

An important sign of CSR is that not only is the corporation itself involved, but so are other parties of corporate relations. While corporate development decisions are made by various subjects, each of them should be held responsible for their actions. For instance, supervisory board members should exhibit a bona fide attitude to possible social consequences when approving an important agreement. The same goes for the shareholders who vote at a general meeting. Concerning the responsibility of a corporation in particular, its personalisation is graded. Naturally, a socially positive corporate image has to become the external attribute

19 'The Ukrainian Economy Is Not Terrible Everywhere' The Economist (London, 2016) <www.economist.com/blogs/freeexchange/2016/01/lviv-not-donetsk> accessed 18 September 2017.

20 National Securities and Stock Market Commission of Ukraine, 'Stock Exchange of Ukraine' <www.nssmc.gov.ua/day_analytics> accessed 18 September 2017.

21 National Securities and Stock Market Commission of Ukraine (2015) 'Annual Report of Ukraine' 61, 64 <www.nssmc.gov.ua/user_files/content/58/1434454281.pdf> accessed 18 September 2017.

22 National Securities and Stock Market Commission of Ukraine (2016) 'Annual Report Ukraine' 92 <www.nssmc.gov.ua/user_files/content/58/1473066406.pdf> accessed 18 September 2017. 
of such responsibility. But the formation of CSR is impossible without the due responsible behaviour of other subjects of corporate relations. This also proves that corporate management bodies should be singled out among the corporate relations subjects as they take an active role in the formation of CSR practices. Corporations are integrated in social life to a certain extent, and this is why they have rights and obligations that no other types of legal entities have. For instance, obligations to form authorised capital enable corporations to be liable for their debts.

In the light of implementing the CSR, the important role of stock exchanges should be stressed. Due to the UN Sustainable Stock Exchanges initiative, 18 global stock exchanges, including the New York Stock Exchange, NASDAQ, the London Stock Exchange, and the German and Italian stock exchanges are participating in the promotion of CSR. One of the priorities of this initiative is environmental, social and corporate management. Unfortunately, none of the Ukrainian or Russian stock exchanges is part of this programme, although there are representatives from Kazakhstan and Belarus. ${ }^{23}$ In this regard, it should be stressed that SCR cannot be implemented by the state itself. A large part of it must be done through market participants. Two major stock exchanges of Ukraine provide no CSR-related data in their reports or ethical codes. ${ }^{24}$ The adoption of the UN Sustainable Stock Exchanges initiative by major Ukrainian stock exchanges is required in this sphere.

\section{Legal component of CSR}

The legal component is extremely important in CSR nowadays. Concerning the definition of the state in terms of the CSR process, it is necessary to consider the opinion of M Friedman who believed that civil society was not able to control the social activities of businesses effectively and could not make them act responsibly. The only power able to do so was 'the iron fist' of government, although this process would mean death for any business. ${ }^{25}$

We consider that CSR has mutual effects upon other types of responsibility: on the one hand, law defines rules of behaviour that the corporation is absolutely bound to comply with; on the other hand, legal standards are called upon to ensure the profitability of the company, and establish environmental and basic ethical norms. In particular, no law can force corporations to undertake charity, but it may well encourage

23 'Sustainable Stock Exchanges (SSE) initiative' <http://www.sseinitiative.org/about/> accessed 18 September 2017.

24 PFTS Stock Exchange <http://pfts.ua/en/1-about-pfts-se> accessed 18 September 2017.

25 Friedman (n 3) 32, 33. 
them to do so. The complexity of this process will depend on such factors as the size of the company and the nature of its activity. For the majority of small and medium-sized companies, especially micro-companies, the CSR process will probably remain informal and intuitive. Nevertheless, the tradition of regulating CSR by public companies is formal.

Under article 3.4 of the Communication, it is the companies themselves that have to develop CSR. Public authorities can play an auxiliary role by skilfully combining voluntary measures and, if necessary, additional regulations, for instance to ensure transparency, and to establish a market incentive for responsible business behaviour and corporate accountability.

The introduction of a legal strategy for CSR may occur on three levels:

- governmental - approval of CSR programmes and laws, as well as the future adoption of a complex law on CSR;

- public - introduction of public control, supervision, regulation and incentives for CSR. This means that both nongovernmental organisations and stock exchanges may act as subjects of the initiative;

- entrepreneurial - large companies have to be active and initiate CSR measures.

The UN defines the state as one of the most important partners in the CSR development process. Thus, the state may become a regulator for CSR between society, corporations and the state itself. UN specialists define the following among the five main public trends of CSR: 1) corporate management; 2) reporting and disclosure; 3) participation of the public and development; 4) responsible management and production (which are the main corporate operations, so they have to be the most important items on the CSR agenda); 5) responsible consumption. ${ }^{26}$

As a rule, the American trend in introducing CSR is characterised by a more voluntary approach; in this, the load of implementing CSR is borne by the public and is based on the social awareness of citizens and corporations alike. For Europe, enhancing the governmental regulation of CSR standards is more characteristic and is based on CSR reporting and accountability. A brief history of this should be studied to make a connection to the implementation of CSR in Ukraine.

We should note that the complex implementation of CSR, as currently seen in European countries, started quite recently. In particular,

\footnotetext{
${ }_{26}$ The Role of Governments in Promoting Corporate Responsibility and Private Sector Engagement in Development <www.vub.ac.be/klimostoolkit/sites/default/files/documents/ role_of_governments_in_csr.pdf > accessed 18 September 2017.
} 
the experience of Denmark in this context is very valuable: in 2008, the Danish Parliament adopted the Act amending the Dutch Financial Statements Act (Report on social responsibility for large businesses). This law was aimed at stimulating corporations to take an active role regarding CSR and to cooperate with other countries in this area. Legislative demands are a part of the First National CSR Action Plan (May 2008), and they should facilitate an increase in the international competitiveness of Danish companies. The law demands large businesses in Denmark to be responsible for their work in the CSR area. In 2013, a new requirement was made stipulating direct responsibility for observing human rights by corporations and for reducing any negative effect they might have on the environment. This law is non-regulatory, ie Danish companies are free to choose whether they want to work based on CSR; however, they have to be guided by CSR policy or have to clearly state their noncompliance. The specified law establishes the following trends of activity in CSR: standards, instructions or principles of CSR used in business; the implementation of CSR policy by businesses, including any systems or procedures used; assessment by businesses of what was achieved by means of CSR initiatives during the financial year, as well as any expectations of the future initiatives. ${ }^{27}$

The Danish experience was used in other EU countries and finally ended up as the basis for Directive 2014/95/EU ${ }^{28}$ amending Directive $2013 / 34 / \mathrm{EU}^{29}$ as regards disclosure of non-financial and diversity information by certain large undertakings and groups. The provisions of this new directive emerged from a compromise between those Member States which are more advanced in reporting non-financial information, such as Denmark and France, and Member States which had previously implemented the minimum requirements stipulated in the Accounting Directive, such as Poland, Germany and the Czech Republic. ${ }^{30}$

Large undertakings which are public-interest entities exceeding the criterion of an average number of 500 employees during the financial year on their balance sheet dates must include a non-financial state-

\footnotetext{
27 Danish Business Authority, 'Legislation' (CSRgov) <http://csrgov.dk/legislation> accessed 18 September 2017.

28 Directive 2014/95/EU of the European Parliament and of the Council of 22 October 2014 amending Directive 2013/34/EU as regards disclosure of non-financial and diversity information by certain large undertakings and groups [2014] OJ L330/1.

29 Directive 2013/34/EU of the European Parliament and of the Council of 26 June 2013 on the annual financial statements, consolidated financial statements and related reports of certain types of undertakings, amending Directive 2006/43/EC of the European Parliament and of the Council and repealing Council Directives 78/660/EEC and 83/349/EEC [2013] OJ L182/19.

30 J Witkowska, 'Corporate Social Responsibility: Selected Theoretical and Empirical Aspects’ (2016) 19-1 Comparative Economic Research 36.
} 
ment in their management report. Regarding Ukraine, it is highly important that the Directive sets obligations not only for public companies but also for public-interest entities to make non-financial reports. The ratio of stock market capitalisation to GDP for Ukraine in 2014 was 29.21\% which fell to $3.21 \%$ in $2015 .{ }^{31}$ This indicator is undoubtedly very low. The ratio of stock market capitalisation to GDP for the US in 2014 was $146 \%$, and $52.58 \%$ for the EU. The reasons for such a decline in Ukraine have been specified above.

Furthermore, some large companies are afraid to register as a company limited by shares while the stock market is still not fully formed. For example, Nova Poshta which is the leader in the private mail delivery market employs 22,000 people, although it is a limited liability company (the LLC form in Ukraine is regulated more like that in the USA and not as in Germany), while Epicentr, the largest Ukrainian construction products supermarket network, hardly has any information on the number of employees. If Ukraine supports the implementation of Directive 2014/95/ EU, then such large off-exchange companies would be bound to file their non-financial reports. It is also important to fulfil provisions concerning consolidated non-financial statements in Ukraine and remember that many Ukrainian enterprises are members of large groups.

In this respect, a CSR report would be the only source of relevant public information regarding some large LLCs which make no public report unless it is legally regulated. This is why it is important to report some corporate information with regard to CSR, Directive 2014/95/EU includes not only CSR action but also some information regarding the undertaking. Within the frameworks of such a report, these companies have to provide the information necessary to understand the company's development, performance, position and the impact of its activity relating to, at the very least, environmental, social and labour force matters, respect for human rights, anti-corruption and bribery matters, including:

(a) a brief description of the undertaking's business model;

(b) a description of the policies pursued by the undertaking in relation to those matters, including the due diligence processes implemented;

(c) the outcome of those policies;

(d) the principal risks related to those matters linked to the undertaking's operations including, where relevant and proportionate, its business relationships, products or services which are likely to cause adverse impacts in those areas, and how the undertaking manages those risks;

31 National Securities and Stock Market Commission of Ukraine (n 21) 26. 
(e) non-financial key performance indicators relevant to the particular business.

Currently, there are fifteen EU countries actively engaged in CSR regulation and public policy development. ${ }^{32}$ In many EU countries, it is the government authorities that propagate and promote CSR. For example, in Italy the process of CSR and social accountability development is controlled by the Ministry of Labour and Social Development. In Spain, left-wing parties actively supported the adoption of the Act on CSR by the parliament in 2003; besides, the State Expert Technical Commission for CSR was established which aims to assist businesses in combining economic activity with other activities for the good of society. In Lithuania, a CSR strategy for 2006-2008 was developed and its implementation helped to improve the position of the country. In Poland, the Ministry of Labour established a CSR work group consisting of representatives of many departments; its activities ensured the stable position of that country in the global social charity rating during the period $2004-2010 .{ }^{33}$ Considering global experience, the development of CSR may be undertaken by the Ministry of Social Policy of Ukraine.

With regard to SOCs, it must be stressed that Directive 2014/95/ EU makes no exception for any company. Further, Member States should ensure the existence of adequate and effective means to guarantee the disclosure of non-financial information by undertakings in compliance with this Directive. To that end, Member States should ensure that effective national procedures are in place to enforce compliance with the obligations laid down by this Directive, and that those procedures are available to all persons and legal entities having a legitimate interest, in accordance with national law, in ensuring that the provisions of the Directive are respected. ${ }^{34}$ SOC policies regarding the CSR report will also bring the Ukraine Act on Governance of State-owned Objects into effect. According to article 11.2.19 of the act, the SOC board is responsible for CSR policy and for the sustainable development of the SOC. Nevertheless, as was shown previously, this norm was not put into effect on the Ukrainian state-owned market.

It should be stressed that CSR report regulation must be made at the Ukrainian legislative level and be introduced as a law.

\footnotetext{
32 'Corporate Social Responsibility National Public Policies in the European Union - Compendium 2014 - Digital Single Market - European Commission'. Digital Single Market <https:/ / ec.europa.eu/digital-single-market/en/news / corporate-social-responsibility-national-public-policies-european-union-compendium-2014> accessed 16 July 2017.

33 V Bulba and M Tretiak, 'Foreign Experience of Governmental Regulation of Corporate Social Responsibility of Businesses' (2013) 3 Theory and Practice of Government Control 346.

34 Association Agreement (n 1) Preamble, art 10.
} 


\section{CSR reporting standards}

Directive 2014/95/EU promotes the 'comply or explain' principle: if a company fails to pursue policies relating to anti-bribery and corruption, environmental, or other non-financial matters, it will have to explain the reasons for such failure in its annual report. The directive instructs Member States to 'ensure that adequate and effective means exist to guarantee disclosure of non-financial information...' and, to that end, that 'effective national procedures are in place to enforce compliance with the obligations laid down by this Directive... 35

Instead of making a non-financial statement, undertakings may produce a separate report drawn up according to an alternative, national, union-based or international framework. The preamble mentions several examples of such frameworks: the Eco-Management and Audit Scheme (EMAS), the UN Global Compact, OECD Guidelines for Multinational Enterprises, ISO 26000 and the Global Reporting Initiative. ${ }^{36}$

Standards need to be elaborated in order to facilitate the implementation of the CSR concept by all enterprises, on the one hand, and to validate and monitor corporate social responsibility which enterprises adopt or declare, on the other hand. Available tools include norms and standards developed by independent organisations, which can be grouped as follows: process-related standards enabling identification of how relationships with stakeholders are shaped and how communication and management systems are built (AA1000, GRI); performance standards identifying volumes of admissibility (Global Compact, ILO Conventions); standards relating to principles which help identify best practices in individual areas (eg OECD Guidelines); certification standards specifying which management systems in certain areas can be certified (SA 8000, ISO14001, EMAS); and review standards providing information concerning the conditions that must be met to assign an enterprise to a certain group (FTSE4Good, DJSGI). ${ }^{37}$

Understanding the need to choose some of those standards for Ukraine to prevent turning non-financial reporting into a formal process, we should make a brief examination of reports. European economists presume that in contrast to the AA1000 Standard and SA8000 standards, the Guidance on social responsibility developed by ISO is an international

\footnotetext{
35 Changes Ahead for Corporate Sustainability Disclosures Following Publication of New EU Directive (2014) 4 <www.willkie.com/ /media/Files/Publications/2014/12/Changes_ Ahead_for_Corporate_Sustainability_Disclosures_Following_Publication_of_New_EU_Directive.pdf> accessed 16 July 2017.

36 Dániel Gergely Szabó and Karsten Engsig Sørensen, 'New EU Directive on the Disclosure of Non-Financial Information (CSR)' (2015) 12(3) European Company and Financial Law Review 337.

37 Witkowska (n 30) 32.
} 
standard that is not subject to certification. The standard does not concern the management system per se, but it contains elements that can be incorporated into existing systems, such as quality management (ISO 9001), environmental management (ISO 14001), and health and safety management (OHSAS 18001/PN-N-18001) (ISO, PKN 2015). It is a document promoting and facilitating business activities in the area of social responsibility. It highlights the relevance of the social responsibility structure, its multidimensional nature, and its connection with the international human rights standards, environmental protection, and anti-corruption areas. ${ }^{38}$

ISO 26000 is the social responsibility standard for all organisations and a derivative of the International Standards. To ensure consistency, ISO has entered into special agreements with the ILO, the Global Compact, the Global Reporting Initiative (GRI)(48) and the OECD. ISO 26000 does not offer guidance on social responsibility performance reporting. However, the ISO 26000 content does cover a very similar range of topics to that in the GRI Reporting Guidelines. The ISO guidance provides a structure for companies to organise their activities, which can then be measured and presented in the company's report following the GRI guidance. No formal accreditation process is available for the ISO 26000 standard. Some countries (eg Germany, Italy) have developed national guidance tools for companies wishing to be ISO 26000 compliant. In some of the Nordic countries, efforts have been made to make stateowned businesses ISO 26000-compliant and to work in partnership in the Nordic region to promote these principles. ${ }^{39}$

Now, CSR is only mentioned twice in the Principles of Corporate Conduct of Ukraine (hereinafter: the Principles). A company introduces an effective system of internal control over the reliability of information disclosed by the company, putting responsibility on the executive body for the reliability of accounting, financial and non-financial information (4.2 Principles). Nevertheless, the Principles do not specify what kind of information the non-financial report should contain, and this cannot be compared with the information provided in Directive 2014/95/EU. Neither do the Principles state whether there are any sanctions in place or explanations for disclosure of such information. Ukraine's Law on Companies Limited by Shares does not provide any such information either. Another reference to CSR in the Principles concerns the fact that the executive body of a company, through its own activities, is aware of its social responsibility for the activities of the given company. However, there is no evidence in what way such awareness must exist.

\footnotetext{
38 Witkowska (n 30) 33-34.

39 N Williamson A Stampe-Knippel and T Weber, 'CSR: National Public Policies in the European Union - Compendium 2014' (European Commission 2014) 16 <http://ec.europa.eu/ social/BlobServlet?docId=12899\&langId=en> accessed 16 July 2017.
} 
Due to the problem concerning the reforms in Ukraine that should be made legally rather than provided by businesses, as the case stands, the implementation of reporting standards is highly important. This is why it must be done through the National Securities and Stock Market Commission of Ukraine. As we may presume, report standards should be recommended for large undertakings which are public-interest entities in the light of the implementation of Directive 2014/95/EU, unless the undertaking provides explanations as to its failure to implement the standards.

\section{Perspectives of CSR regulation in Ukrainian legislation}

According to the Association Agreement, parties must strive to facilitate trade in products that contribute to sustainable development, including products that are the subject of schemes such as fair and ethical trade schemes, as well as those respecting CSR and accountability principles. ${ }^{40}$ Another article of the Association Agreement provides that the parties must promote CSR and accountability, and encourage responsible business practices, such as those promoted by the UN Global Compact of 2000, the International Labour Organization (ILO) Tripartite Declaration of Principles concerning Multinational Enterprises and Social Policy of 1977, as amended in 2006, and the OECD Guidelines for Multinational Enterprises of 1976, as amended in $2000 .{ }^{41}$ It is significant that the Association Agreement puts CSR before economic principles, meaning accountability in this field. It is determined that trading must be done in a manner that respects CSR. This means that not only must business affairs be conducted in compliance with CSR, but CSR itself has to be strongly incorporated in Ukrainian legislation.

In this relation we might assume that legal regulation of CSR must be done in several ways: by implementing the CSR principles in the legislation itself and by including CSR information in the financial reports of public companies, as was considered earlier.

We should note that the Economic Code of Ukraine contains several provisions where CSR is mentioned:

- as the preamble states, the Economic Code is aimed at ensuring the growth of the business activities of enterprises, the development of entrepreneurship and the resulting increase of public production efficiency and its social orientation in conformity with the requirements of the Constitution of Ukraine, the establishment of public business procedures in the economic system

\footnotetext{
40 Association Agreement (n 1) art 293(2).

41 Association Agreement (n 1) art 422.
} 
of Ukraine, and the facilitation of its harmonisation with other economic systems;

- entrepreneurship is defined as a business activity carried out to achieve economic and social results as well as aimed at gaining profit (part 2 of Article 3 of the Economic Code of Ukraine).

The social features of the general business principles defined in the Economic Code prove the need to introduce CSR in economic law once more, as the branch already has some experience regarding the social nature of governmental regulation of economic activities in terms of a socially oriented economy.

Directive 2014/95/EU is not mentioned in the Association Agreement, as it was adopted later. In spite of what was mentioned above, the Directive must be implemented with due consideration to Directive 2014/95/EU of the European Parliament and the Council dated 22 October 2014, amending Directive 2013/34/EU regarding disclosure of nonfinancial and diversity information by certain large undertakings and groups, and Directive 2013/34/EU on the annual financial statements, consolidated financial statements and related reports of certain types of undertakings, amending Directive 2006/43/EC of the European Parliament and the Council and repealing Council Directives 78/660/EEC and 83/349/EEC.

Annex XXXV to Chapter 13 'Company Law, Corporate Governance, Accounting and Auditing' states that Ukraine undertakes to gradually approximate its legislation to the following EU legislation within the timeframes stipulated by Directive 2006/43/EC of the European Parliament and the Council dated 17 May 2006, on statutory audits of annual accounts and consolidated accounts, amending Council Directives 78/660/EEC and 83/349/EEC. The Directive provisions must be implemented within 3 years of the commencement of the Agreement. The Association Agreement entered into force on 1 September 2017. For this reason, the provisions of Directive 2014/95/EU should be implemented by 1 September 2020 .

Currently, there is a Draft Law on Amendments to the Law on Accounting and Financial Reporting in Ukraine (regarding improving some of its provisions) (hereinafter: Draft), ${ }^{42}$ filed with the Verkhovna Rada of Ukraine (the Supreme Council). The Explanation Note to the Draft states that the Draft envisages the inclusion of a part of the basic provisions of the new Directive 2013/34/EC in the Law. ${ }^{43}$ There is no such determina-

42 In general, the requirements of Directive 2013/34/EC are planned to be gradually implemented by adopting regulatory acts, primarily, by amending the provisions (standards) of accounting.

43 Draft Bill <http://search.ligazakon.ua/1_doc2.nsf/link1/GH3L200A.html> accessed 6 September 2017. 
tion regarding the non-financial reports. Instead, the Draft provides for the management report - a document containing financial and non-financial information that characterises the status and prospects of development for the enterprise and revealing the main risks and uncertainties in its activities.

For the purposes of understanding the management report, we should consider article 19 of Directive 2013/34/EU, which has detailed information regarding indications. In contrast to Directive 2013/34/EU, the Draft establishes no type of enterprise or scope of information which should be included in the management report. Furthermore, the Draft contains a corresponding article establishing the procedure and terms for filing financial statements, consolidated financial statements, management reports and reports of payments made for the benefit of the state, to governmental authorities, as determined by the Cabinet of Ministers of Ukraine, and similar requirements for banks as determined by the National Bank of Ukraine. It is not clear why such an important part of Directive 2013/34/EU regarding non-financial information is going to be implemented not by the Verkhovna Rada of Ukraine (the principal legislative authority) but by the Cabinet of Ministers (which is an executive authority).

Member States must ensure that the statutory auditor or audit firm checks whether the non-financial statement or a separate report has been provided. The main enforcement mechanism related to the non-financial reporting requirements is a compulsory check by the auditor. ${ }^{44}$ The Draft does not pay attention to the auditor check of the non-financial report (it should be noted, however, that the auditing and disclosure of the financial report is prescribed in the Draft). The rules regarding the audit of non-financial reports should also be included in Ukrainian legislation.

It is not clear why the provisions of Directive 2014/95/EU, amending Directive 2013/34/EU, are not reflected in the Draft. It might be the subject of further drafts, but, as it appears, it would be better to implement Directive 2013/34/EU jointly with Directive 2014/95/EU. The lawmaking process shows that Ukraine is currently failing to heed the need for CSR, and this is why the CSR strategy must be fulfilled as discussed below.

\section{Strategy}

In the light of significant changes that must be made in Ukrainian legislation regarding the perception of CSR, a government strategy is presumably needed in this field. As the research reveals, state control and

44 Szabó and Sørensen (n 36) 336. 
guidance regarding CSR implementation is highly important. The recent development of such implementation includes drafting the National Action Plan. Within five years of its unanimous approval in June 2011 by the United Nations Human Rights Council (UN HRC), the United Nations Guiding Principles on Business and Human Rights (UNGPs) have become the first globally accepted standard covering the responsibilities of states and businesses in preventing and addressing business-related human rights abuse, and thus the authoritative point of reference for all those working to ensure business respect for human rights. A common global platform for action has been established, upon which cumulative progress has started to be recorded. Unanimous endorsement by the United Nations (UN) has made the UNGPs a legitimate document to be taken up in discussion with states around the world that would not otherwise enter into discussion on human rights and business. ${ }^{45}$

The global business community must continue and accelerate its work to fully respect human rights throughout its operations. But without concerted action from all states in all regions of the world, the vision of the Guiding Principles will not be fully achieved. Not only are the rights of the most vulnerable at stake, but business thrives when operating in jurisdictions with stable operating environments that support the rule of law, justice, human rights, and sustainable development. Where possible, business welcomes consistency amongst states. For these reasons, business welcomes National Action Plans as a mechanism to set out expectations and map ways forward. ${ }^{46}$ However, up to 31 December 2016, only twelve countries, ten of which are in Europe, have produced National Action Plans: the United Kingdom (UK) $(2013,2016)$, the Netherlands (2013), Denmark (2014), Finland (2014), Lithuania (2015), Sweden (2015), Norway (2015), Colombia (2015), Switzerland (2016), Germany (2016), Italy (2016) and the United States (2016).$^{47}$ In this respect, Ukraine has an opportunity to set CSR standards on the newest level by setting the UNGPs into action in Ukrainian legislation.

Here we should comment on the requirements of the National Action Plan regarding implementation of CSR. Directive 2014/95/EU does not

\footnotetext{
45 Implementation of the UN Guiding Principles on Business and Human Rights 8 <www. europarl.europa.eu/RegData/etudes/STUD/2017/578031/EXPO_STU(2017)578031_ EN.pdf > accessed 16 July 2017.

46 Statement on National Action Plans on Business and Human Rights. Session at the UN Annual Forum on Business and Human Rights / 'National action plans to implement the UN Guiding Principles: stepping up Government commitments and action' 16 November 2016 <https://cdn.iccwbo.org/content/uploads/sites/3/2017/01/ICC-STATEMENT-ONNATIONAL-ACTION-PLANS-ON-BUSINESS-AND-HUMAN-RIGHTS-2016.pdf > accessed 16 July 2017.

47 Implementation of the UN Guiding Principles on Business and Human Rights $8<w w w$. europarl.europa.eu/RegData/etudes/STUD/2017/578031/EXPO_STU(2017)578031_ EN.pdf> accessed 2 September 2017.
} 
refer to Member States implementing national action plans. Such developments have begun with regard to the Commission's Communication. Member States were to develop or update by mid 2012 their own plans or national lists of priority actions to promote CSR in support of the Europe 2020 strategy, with reference to internationally recognised CSR principles and guidelines and in cooperation with enterprises and other stakeholders, taking account of the issues raised in the Communication. ${ }^{48}$

In this context, the Preamble (10) of Directive 2014/95/EU states that:

Member States should ensure that adequate and effective means exist to guarantee disclosure of non-financial information by undertakings in compliance with this Directive. To that end, Member States should ensure that effective national procedures are in place to enforce compliance with the obligations laid down by this Directive, and that those procedures are available to all persons and legal entities having a legitimate interest, in accordance with national law, in ensuring that the provisions of this Directive are respected.

In this respect the Ukrainian government does not have an obligation to make a National Action Plan regarding CSR implementation. But, as may be seen from the experience of EU Member States, such a document is important as the beginning of the implementation of Directive 2014/95/EU. As Ukraine is only at the start of the enforcement of CSR laws, it might also be methodologically important to have a clear perspective of the application of CSR.

\section{Gender Diversity}

The participation and representation of women in corporate administration bodies is provided within the framework of CSR development. Currently, this issue is resolved neither in Russian nor Ukrainian legislation. Nevertheless, many EU countries have already introduced the requirements regarding the minimal number of women in corporate administration bodies. There is an EU-wide process currently running to stimulate and set up discussion on, and the adoption of, the Directive on improved gender balance among non-executive directors of companies listed on stock exchanges of 14 November 2012, which aims to establish a quota for female non-executive directors at the level of $40 \%$ by $2017 .{ }^{49}$

\footnotetext{
48 Communication (n 8) A 4.7.

49 A Masselot, 'Balanced Representation between Men and Women in Business Law: The French "Quota" System to the Test of EU Legislation' (2014) 3(2) CELLS Online Paper Series 25.
} 
Directive 2014/95/EU provides a description of the diversity policy applied in relation to corporate administrative, management and supervisory bodies with regard to aspects such as age, gender, or educational and professional backgrounds, the objectives of that diversity policy, how it has been implemented and the results achieved during the reporting period. If no such policy is applied, the statement must contain an explanation of why it has not been applied. ${ }^{50}$

The procedure of initiation to adopt the Directive commenced in the background of the introduction of a successful quota of females in EU countries. The first to introduce quotas for female members on the supervisory board was Norway in 2008; then this initiative was joined by Spain, France, Iceland and Belgium. These countries have a $40 \%$ quota for female representation in the supervisory council or on the board of directors, while several other countries provide a slightly lower quota, in particular, 1/3 in Italy, 30\% in Belgium, the Netherlands and Germany (where the respective law was adopted in 2015). Great Britain provides no quotas for female representation on boards of directors; however the average number of women in corporate management bodies makes up $23 \%$. In the USA, this index is slightly lower - $17 \%$ - while all legislative attempts to set it as high as 30\% have been strongly resisted. ${ }^{51}$

We believe that one of the important elements of CSR in Ukraine is to determine the minimum number of women in corporate management bodies. It is important for law makers to pay attention to this problem and to take sufficient measures to resolve it. It should be noted that it is the companies limited by shares and large limited liability companies that will be the main CSR subjects as they are the large players on the market and have a direct effect on the social, innovative, environmental and other aspects of the life of the state and on society as a whole.

\section{Conclusions}

A platform to develop CSR may be established within the framework of corporate law, with the application of standards and norms from other branches of law regarding the Association Agreement. European practice in the introduction of CSR proves the need for legislative regulation. Despite the participation of many Ukrainian companies in the CSR process, CSR reporting is not regulated either by Ukrainian laws (not even draft laws) or other public regulations. The basis for the legal development of CSR in Ukraine should be implemented at the legislative level for large

50 Directive 2014/95/EU, art 2.

51 A Smale and C Miller, 'Germany Sets Gender Quota in Boardrooms' The New York Times (New York, 6 March 2015) <www.nytimes.com/2015/03/07/world/europe/german-lawrequires-more-women-on-corporate -boards.html?_r=0> accessed 16 July 2017. 
undertakings which are public-interest entities, with full regard to Directive 2014/95/EU.

The current legal law-making process shows that Ukraine fails to be aware of the need for CSR, and for this reason a CSR strategy must be drawn up. It is highly important to stress that implementation must be carried out by the legislative body of Ukraine - the Verkhovna Rada. This conclusion is made not only because of the analyses of Directive $2014 / 95$, but also in order to provide relevant implementation of CSR reporting and its entry into force in Ukraine.

In order to ensure CSR at a modern level, a management report or a non-financial statement should contain information as established by Directive 2014/95/EU. If a public-interest entity refuses to write a CSR report, it has to specify reasons for such a refusal. Special attention should be paid to the social responsibility of major corporations and the prospects of their enhancement, as well as changes in their identity while taking into account the important social level. The auditing issues of the CSR report should also be legally regulated.

All these concerns create the need for a National Action Plan to be made and established by the Ukrainian government in the same manner used to introduce CSR in most European countries. The National Action Plan will help form a legislative, executive and civil strategy to introduce CSR into Ukrainian businesses. 